Asia Pacific, 2020

Vol.38, pp. 87 - 108

\title{
CORRELATION BETWEEN RELIGIOUS MOTIVES AND THE PERSONAL WISH OR FAMILY CHOICE AS REASON OF VEILING AMONG MALAYSIAN MUSLIM UNIVERSITY STUDENTS
}

\author{
Naima Tabassum* \\ Tabassum Afzal ${ }^{+}$ \\ Abdul Hadi
}

\begin{abstract}
This paper is part of the broader research to investigate Malaysian university student's veiling pattern and their motives to adopt and using veiling. This paper particularly focuses on relationship between religious motives and the personal wish or family pressure as the reason of using veiling articles among Malaysian Muslim University students. The data were collected through survey method with the help of a closed ended questionnaire from 335 female (Muslim and non-Muslim) university students of University Malaysia Perlis. After processing of Data 255 cases of veiling Muslim university students were included in this research paper. The research tool for this research study comprises of three broader main scales to assess the practice of veiling due to religious motives, personal wish, and family pressure among these students. The data were analyzed to identify the relationship between religious motives behind veiling and the choice made by the student's personal wish for veiling or due to their family pressure to veil by applying Pearson correlation. The results show a statistically significant positive relationship between religious motives and the personal wish of veiling among Malaysian Muslim university students.
\end{abstract}

Keywords: Veiling, Malaysian university students, Religion, Personal choice, Family pressure.

*Associate Professor, Area Study Center, University of Sindh.

Email: naima.tabassum@usindh.edu.pk (Corresponding author)

+Assistant Professor, Department of Education, University of Karachi.

$\ddagger$ Assistant Professor, Department of Sociology, Harran University, Turkey. 


\section{INTRODUCTION}

The word 'Veil' means a thing that hides or disguises and its literal function is defined as 'to cover' (Thompson, 1993, p. 1019). It is also referred as a piece of cloth to cover human body, especially of women. It has been referred to take various forms from a small net attached to women's hat (Thompson, 1997, p.1553), a small piece of cloth covering some parts of the body (Hochel, 2013, p.41), to a big large piece of cloth covering the whole body from head to toe (Hoodfar, 1991, p. 7).

The veil has been used in one or another form in various religions and societies across the world (Almila \& Inglis, 2018). The vast span of the veiling among different religions is evident from the fact that it is being practiced among Jewish (Elor, 2018), Christian (Hawley, 2018), Hindu (Abraham, 2018) and Muslim societies (Abraham 2018; Arshad, Basar, Zafar \& Ahmad, 2012; Farhatullah, Nizar, Ahmad, Ali \& Shah 2014; Leibold \& Grose, 2016; Sunesti 2016; Utomo, Reimondos, McDonald, Utomo \& Hull, 2018). The geographical span of societies with veiling practiced is also large enough (Almila \& Inglis, 2018). It is being practiced in India (Abraham, 2018), Pakistan (Arshad, Basar, Zafar \& Ahmad, 2012), Bangladesh (Sultana, Jawan, \& Hashim, 2009), Iran (Zahedi 2008), United Arab Emirates (PashaZaidi, 2015), Israel (Elor, 2018), Turkey (Gökarıksel \& Secor, 2012), South Africa (Naidu, 2009), Nigeria (Yusuf, 2014), Britain (Dwyer, 2008), Cameroon (van Santen, 2010) and United Sates of America (Reeves, McKinney \& Azam, 2012).

The veil has also been practiced in different countries in the Far East and Southeast Asian region; such as China (Leibold \& Grose, 2016), Thailand (Lateh \& Mudor 2014), Indonesia (Candraningrum, 2013; Utomo, Reimondos, McDonald, Utomo \& Hull, 2018), and Malaysia (Hassim, 2014, 2014a, 2017; Halim, 2018; Hochel, 2013; Sunesti, 2016, Chowdhury, Elmetwally \& Bakar, 2017). This paper particularly focuses on the veiling of Muslim women in Malaysia. The veiling 
articles namely tudung or mini telekung (i.e. varieties of piece of cloths of different length used as headscarf) are used as traditionally essential parts of the Malay women's traditional dress code (Lie, 2000, p. 33).

The nature, purpose and motives of practice of veiling is variously interpreted in religious, social and political terms. In religious terms, more particularly in Islamic interpretations, veil is a divine instruction given in Quran (in Surah Alnur verse 31 and Surah Alahzab verse 59) to be followed by women to cover their body with their outer cloths (Arshad, Irfan, Zaman, Arshad \& Shahzad, 2013; Latiff \& Alam, 2013). In sociological terms, it is defined as a gendered practice confirming the both genders to follow the gender stereotypes set in society. In its transformative forms, this has also been discussed as fashion (Hochel, 2013, p. 52) and symbol of more liberal and progressive image of Muslim women's empowerment (Hassim, 2014a; Chowdhury, Elmetwally \& Bakar 2017). As a political tool, it is considered important in giving shape to local political dominant identities in multi-ethnic and multicultural societies in the world (Sunesti, 2016).

The west has interpreted veiling of Muslim women as oppression, suppression, imposition and seclusion of Muslim women without their own will (Hirschmann, 1997). A counter argument to this western image has led in production of discourse on women's agency (Mouser, 2007; Hassim, 2014a; Chowdhury, Elmetwally \& Bakar, 2017) and their will and choice to veil (Hochel, 2013, p. 44). They identify that women are not passive and static recipients of this social, cultural and political feature assigned to them. Women use their agency to maximize their interest out of this seemingly constraining resource (Mouser, 2007, p. 164). Their activism in this effort lead to opening of new avenues of gaining empowerment when transforming, manipulating and renewing this given traditional resource (Hassim, 2014a). 
Media as agent of change in Muslim societies is also shown deliberately promoting veiling in a new more fashionable forms (Latiff \& Alam, 2013). It is promoting presentable and progressive forms of Muslim women's image while maintaining veil as a part of traditional Islamic identity (Hassim, 2014, 2014a, 2017). The common Muslim women seems to be practicing it to maintain their image fulfilling the social pressure (Mouser, 2007) and the desires generated from media as discussed above.

To encompass a variety of reasons of veiling in the vast geographical, societal, and social class related span of the global phenomenon of veiling was beyond the limited scope of any single research paper. Therefore, this research paper mainly focuses on the relationship between two main aspects of veiling namely: 1) Religious motives of adopting veil; and 2) The matter of personal choice or imposition of veiling (by family) on women. Geographically, the scope of this research paper is limited to Malaysia, in general, and the University of Malaysia Perlis, in particular. The religious scope of the paper is limited to Muslim women. The segment of women in Malaysian society targeted in this research are young university students. Accordingly, the research paper specifically aims to explore the correlation of the religious motives of veiling with their personal wish or family pressure of veiling among female Muslim Malaysian university students.

\section{LITERATURE REVIEW}

\section{Defining veil and its features}

Literally, the word veil can be defined as curtain or screen (Thompson, 1997, p.1553). But it commonly means a piece of cloth to conceal whole or some part of body, especially of women. It is defined in dictionary as almost transparent fabric hanging with a woman's head wearing to cover the face (Thompson, 1997, p.1553). The part to be covered through this veiling cloth also have some different views in literature. Sometimes referred as the concealment of whole body 
leaving some parts visible, it is considered either a big or small piece of clothing that is aimed to hide the body from head to toe, except face (or its some parts), hands, and feet (Hoodfar, 1991, p. 7). Some scholars consider it a concealment for some parts of the body leaving the larger portion of body uncovered with this additional clothing. Hochel (2013, p. 41) considers it comprising either a mere head scarf covering the face, neck and hair or a part of a bigger piece of cloth that covers face or eyes. Farhatullah, et. al., (2014, p.105) have claimed it as an Islamic head cover. In an encompassing manner, Human Rights Commission (2005, p. 8) has identified it as Muslim women's traditional head, face or body cover taking large number of variations appearing in different time and places across the world.

\section{Islamic view of veil}

Veil is claimed as religious statement of Islamic way of living (Hochel, 2013 , p. 40). Some scholars claim that it results from devotion and obedience to Allah (Doblado, 2012, p. 7) in a way that has been defined in Quran and Sunnah (Latiff \& Alam, 2013, p. 50). This is considered as a religious obligation for Muslim women (Arshad, Irfan, Zaman, Akhtar \& Shahzad, 2013). It is argued that, as a divine decree, the purpose of the veil as declared in Quran is to avoid glance of strange men (Beck, 1997, p. 195).

Warren has identified that 'Islam is not only a religion: it is one of the oldest and most well-developed legal systems in the world' (2008, p. $34)$. In the hierarchy of the sources of laws in Islamic social system, 'The Qur'an is the most authoritative guide for Muslims and the first source of Shari'ah law' (Warren, 2008, p. 35-36). The Quran, in Surah Alnur's Ayat 31, has clearly instructed believing women to lower their gaze and be modest and also to lower their veils over their bosoms. It is further elaborated, in Sura Alahzab's Ayat 59 of The Quran, for believer women to draw down their cloth to cover their body so that they will appear to people as believers and people will not have courage to disturb them. 
The matter of disturbance in public sphere may possibly referred to what is now called as sexual harassment in public sphere. Warren (2008) argues that 'The Quran counsels women to cast their outer garments over their persons when they are outside so they will not be molested' (p. 40). It is claimed that this objective of veil is being realizing in practical life. Arshad, Basar, Zafar and Ahmad (2012) have identified the link between wearing veil and decrease in possibility of sexual harassment. They have reported that women practicing veil are reporting to be less encountering sexual harassment incidents at workplace.

In addition to the above Quranic verses instructing women to veil, The Quran also has given parallel instructions for men to keep their 'eyes down' in Surah Alnur's Ayat No. 30. From sociological point of view, it can be argued that, through Quranic instructions, Islam has repeatedly referred veiling and lowering of gaze by Muslim men and women (in Surah Alnur's Ayat No. 30 and 31) as a practice to foster protection of women citizens and maintain social order in society. It also seems to hold both men and women responsible to avoid any social disorder in Islamic society.

Veil is also linked with the globalization of Islam and the modernization in Muslim societies. Göle (1953, p. 83) has called the veil as a vehicle for making Islamization visible at global level. Latif and Alam (2013, p. 51) have identified that in modern times Islamic groups have promoted veil to symbolize the Islamic identity. It is considered a form of Islamic way of piety held by women (Doblado, 2012, p. 6).

\section{Veiling in Malaysia}

The particular geographical focus of this research is on Malaysia. Malaysian women traditionally use tudung/tudong or mini telekung as traditional veiling articles added in customary Malaysian dress code (Lie, 2000, p. 33). Mouser (2007) has explained tudong as 'a headscarf' or 'veil' (a form of purdah) that covers a women's hair from public 
view' (p. 169). Izharuddin (2018, p.157) explains that in Malay language tudong means 'cover' and locally it is understood as connoting ' $h i j a b$ '. Mouser (2007) claims that in the beginning when tudong was adopted as a part of customary dress for women in Malaysia, it was mainly representative of women affiliated with Islamic (Dakwah). Now it has transformed into a social expectation for all Malay women (Mouser 2007, p. 169).

There is research available on a variety of aspects of veiling in Malaysia. Frisk (2009) discussed the religious effects of veiling on women in Malaysia. Hassim's several research works (2014, 2014a, 2017) focused on veiling practice as a transformative socialization of Malay women through media in multicultural Malaysia. Hochel (2013) explored meanings that women in Malaysia assign to head covering and she further evaluates the reasons of their veiling practice. Mouser (2007) highlights women's agency in transforming, utilizing and renegotiating the Islamic veil for their better social position. Chowdhury, Bakar, \& Elmetwally, (2017) studied the phenomenon from phenomenological aspect identifying it as a personal choice of women and expression of Islamic identity. Sunesti (2016) has comparatively discussed the social imaginary about veiling of Muslim women in the context of multicultural politics in Malaysia and Indonesia.

Hassim's research papers (2014, 2014a, 2017) are focusing media movement and presentation of veiling among Malay women to promote it as a modern and progressive life style. Hassim (2014) have comparatively explored hijab wearing patterns in two magazines for Muslim women in Malaysia namely Nur and Hijabista. Hijabista has been found promoting a fashionable and glamorous aspect of hijab among urban Malaya communities with minimum discussion done on religious aspect of veil (Hassim, 2014). Further, in another research, Hassim (2017) has identified that along globalization of veiling as a symbol of progressive identities in Muslim majority countries, the local level social and political developments are also 
important to understand. She studies the media campaign to provide this transformative progressive identity to Muslim Malay women. Hassim (2014a) in another research shows that increased portrayal of Islamic modesty through veil in media has opened the opportunities for empowerment of Muslim women.

\section{Reasons of veiling in Malaysia}

Different scholars have discussed variety of reasons of veiling among Malaysian women such as Islamization of Malaysian society (Stivens, 2006, p. 358), social pressure (Izharuddin, 2018), personal level religious motives (Frisk, 2009; Hochel, 2013), women's personal choice and empowerment (Chowdhury, Elmetwally \& Bakar, 2017), and fashion and inspiration of media (Hassim, 2016), etc. The three main reasons of veiling as religious motives, social pressure and personal choice will be discussed in the following paragraphs.

\section{Veiling in Malaysia due to Islamic motives}

Stivens (2006, p. 358) states that the widespread adoption of veiling by Malay women in almost last four decades is a most apparent symbol of Islamization process. Yuyun Sunesti (2016) highlights a prevailing social imaginary of veiling in Malaysia 'as a pious practice of Muslim women based on Islamic teachings' (p. 149). Hassim's (2016) study highlights the role of social media as an agent of socialization creating a desire among consumer women to have a 'more modern yet Islamic lifestyle' (p. 62). The Malay women practicing veiling also reported to experience transformative effects of veiling in terms of religious aspects (Frisk, 2009, p. 96). Their motive of veiling is a desire to become close to God. They practice veiling as an obedience to Allah's will and a source to strengthen their faith (Frisk, 2009). Hochel (2013, p. 50-51) identified that the primary reason of veiling among Malay women respondents in her study is religious obedience. 
Some scholars claim that Malay women practice covering because of fashion or convention not due to religious motives (Hochel, 2013, p. 52). The veil (as tudung or mini telekung) is considered a part of the Malay women's traditional dress (Lie, 2000, p. 33). Still it is reported to be a symbol of devotion (Hochel, 2013, p. 48). Similarly, Grine and Saeed (2017) exploring religious obligation or fashion as motives of Malaysian women's wearing of hijab found that most of them adopt hijab as a religious obligation instead of fashion motivation.

\section{Social pressure for veiling in Malaysia}

The social pressure on Malaysian women to veil or not to veil exerted by society or family is also a relevant aspect of the phenomenon to be discussed here. Mouser (2007) points out that practicing veil is a social expectation for Malay women. Izharuddin (2018) claims that majority of Muslim women in Malaysia except those from elite class experience social and religious pressure for wearing a veiling article called Tudung. She further claimed that 'not wearing the tudung can trigger public opprobrium, bulling, and abuse' (p. 157).

Stivens (2006) argues that concepts related to gender relations and the family hold critical role in reinventions of Islamic ideas in Malaysia. She elaborating the role of family and parents states:

The family is presented as a critical site for producing new versions of purer Islam, and parents, especially women, within it carry a large responsibility for securing an Islamic future through the rearing of children (p. 358).

Hochel (2013) narrates that if some Malaysian women face considerable pressure from family to cover, but at the same time a few also have family pressure no to cover. These are suggestive evidences available in literature that family as an important institution of society while enforcing Islamization and new ideologies of Islam in Malaysia may also have promoted this through Malay women and their particular veiling practice. Still there is lack of literature that thoroughly discuss the role of family in pressurizing the women to 
adopt veiling in the country.

\section{Veiling and the personal choice of women}

Some scholars do not look at veiling as simply something introduced through culture, religion, media or local socio-political dynamics without women being part of this whole development (Mouser 2007; Hassim 2014a; Chowdhury, Elmetwally \& Bakar 2017). They brought women's agency in this discourse. Mouser (2007) argues that women advantageously alter, transform and utilize the constructs placed upon them by Islam, by ethnic identification and by conceptions of 'modernity' (p. 164). It is identified that women renegotiate this religious and cultural construct and use it in a way that it becomes the symbol of their freedom in a modern industrial society (Mouser, 2007).

Hassim (2014a) has also focused his research on role of Malaysian Muslim women in promoting new liberal Muslim identify in Malaysian society through presentation of new ways of veiling in media. Chowdhury, Elmetwally and Bakar (2017) have argued that niqab/ veil wearing is a choice of individual women, her empowerment and her expression of Islamic identity. They strive to highlight the link between women's choice of veiling and their Islamic motive (Chowdhury, Elmetwally \& Bakar, 2017). Hochel (2013) claims that Malaysian people stress with pride that 'the choice of whether to cover is the women's' (p.44).

Therefore, this research explores the link between the adoption of veiling as reported due to religious motives and a parallel reporting of adopting veiling by women's personal choice or by family pressure or imposition. The research is done in the context of Malaysian society with young Muslim female university students. 


\section{OBJECTIVES}

- To understand the process of making choice of veiling (either by women herself or by family) if motivated to veil by the religious factors.

- To identify the relationship between religious motives of the veiling and the personal wish to veil among Muslim Malaysian university students.

- To identify the relationship between religious motives of veiling and the family pressure for veiling among Muslim Malaysian university students.

\section{HYPOTHESES}

$\mathrm{H}_{1}$. The mean score acquired on the scale of religious motive of veiling has statistically significant positive correlation with the mean score on the scale of personal wish to veil among female Muslim Malaysian university students.

$\mathrm{H}_{2}$. The mean score acquired on the scale of religious motive of veiling has statistically significant positive correlation with mean score on the scale of family pressure to veil among female Muslim Malaysian university students.

\section{VARIABLES OF THE STUDY}

This research paper is focused on three causes of veiling among Malaysian Muslim university students as shown in Figure 1. The aim of the paper is to identify correlation of one independent variable namely 'religious motives to veil' with two dependent variables namely 'personal wish to veil' and 'family pressure to veil' among Muslim Malaysian university students. 


\section{Independent Variable Dependent Variables}

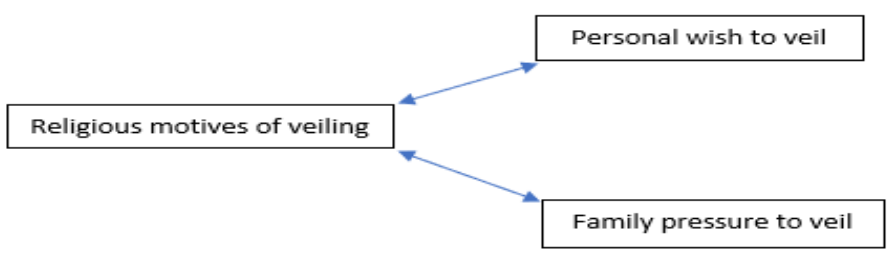

Figure.1: Variables of the study

For the sake of operationalizing the puzzling duo of choice or imposition, this research takes the matter of choice in terms of veiling women's reports of their personal wish for veiling. The matter of imposition is narrowly dealt in the reports of women respondents about pressure of family members to adopt veiling.

\section{RESEARCH METHODOLOGY}

This paper is part of a broader research study designed to be done in the positivist paradigm with empirical data acquired through survey method. The research study is exploratory, correlational, and cross sectional in nature. The geographical scope of the study is limited to Malaysia, in general, and University Malaysia Perlis, in particular. The primary data for the broader research study were collected through survey of 335 female students (including Muslim, nonMuslim, veiling and non-veiling students) selected through random sampling in University Malaysia Perlis.

The focus of this research paper is on the correlation between abovementioned three causes of veiling among female Muslim Malaysian University students. Therefore, according to the particular scope and purpose of this research paper, the cases in data set fulfilling the two main criteria of being 'Muslim students' and 'practicing veiling' are selected (i.e. 255 cases) for data analysis of their reported causes of practicing veiling. 
The data set analyzed for this research paper was collected with the help of a research tool including three scales (each addressing one variable of the study, namely religious motives of veiling, personal wish to veil, and family pressure to veil) comprising of 11 items. Items of the scales are based on 5 point Likert scale answer categories. The reliability of the three scales was assessed through calculating Cronbach's Alpha as presented below in Table 1.

Table 1: Reliability statistics for scales (Cronbach's Alpha)

\begin{tabular}{llc}
\hline \multicolumn{1}{c}{ Scales } & $\begin{array}{c}\text { Cronbach's } \\
\text { Alpha }\end{array}$ \\
\hline 1 & Religious Motives (RM) & .8002 \\
\hline 2 & Personal wish as motive behind veiling (PW) & .7116 \\
\hline 3 & Family Pressure as reason behind veiling(FP) & .9567 \\
\hline
\end{tabular}

The researchers visited Malaysia in person and collected data in University Malaysia Perlis with the help of a team of Malaysian academicians in the university. The respondents were explained about the research scope, aim and purpose. They were delivered a consent form asking for their formal free consent to participate in this research by filling the form.

The data collected was coded and entered in the computer. Computer software like Microsoft Excel and SPSS were utilized to enter, process and analyze data for this research. The variables of the study were measured at interval level. The data collected and computed on each variable was continuous scale data. The Chi Square test of association/independence between variables is applicable to categorical/ordinal data for variables measured on nominal/ordinal level. It is not applicable on the interval/ratio level continuous data acquired through scales (Miller, Acton, Fullerton, \& Maltby, 2002, 241). The data on three variables of the study is acquired on three scales. Therefore, Pearson's product-moment correlation coefficient $(r)$ was found suitable to test the above hypotheses exploring 
relationship between variables. The results of data analysis are presented in the forms of tables below showing mean scores on the scales, correlation coefficient $(r)$, and Sig. $(p)$ values.

\section{DATA ANALYSIS AND PRESENTATION}

The data was analyzed to test the hypotheses stated above and the results are presented in this section of the paper. This section of paper is divided into two parts addressing two hypotheses developed. First part focuses on the relationship between religious motives as reason behind veiling of university students and their personal wish of veiling. Second part analyses the relationship between religious motive of veiling and the family pressure as reason for their veiling practice.

\section{Relationship between religious motives of veiling and the personal wish of student}

The data was analyzed to find the relationship between young female Muslim Malaysian university students' adoption of veiling due to religious motivation and their personal choice of veiling. The university students have reported their responses on two scales. One scale is showing the extent of their veiling due to religious motivation. The other scale of personal wish as reason of veiling assess the extent of their personal choice as being a motivation behind adoption of veiling practice.

Table 2: Descriptive Statistics

\begin{tabular}{lccc}
\hline & Mean & Std. Deviation & N \\
\hline Religious motives & 27.8902 & 2.82210 & 255 \\
\hline Personal wish & 8.9686 & 1.38858 & 255 \\
\hline
\end{tabular}

The data analysis presented in above Table 2 shows that young female Muslim Malaysian university students $(\mathrm{N}=255)$ who are practicing veiling presently are scoring a mean of $27.8902(d f=2.82210)$ on the 
scale of religious motives as reason of veiling. At the same time the respondents have scored a mean of $8.9686(d f=1.38858)$ on the scale of personal choice as reason of veiling.

Table 3: Correlations of religious motives and personal wish

\begin{tabular}{|c|c|c|c|}
\hline & & $\begin{array}{l}\text { Religious } \\
\text { motives }\end{array}$ & $\begin{array}{l}\text { Personal } \\
\text { wish }\end{array}$ \\
\hline \multirow[t]{3}{*}{ Religious motives } & $\begin{array}{l}\text { Pearson } \\
\text { Correlation }\end{array}$ & 1 & $.521(* *)$ \\
\hline & Sig. (2-tailed) & . & .000 \\
\hline & $\mathrm{N}$ & 255 & 255 \\
\hline \multirow[t]{3}{*}{ Personal wish } & $\begin{array}{l}\text { Pearson } \\
\text { Correlation }\end{array}$ & $.521(* *)$ & 1 \\
\hline & Sig. (2-tailed) & .000 & . \\
\hline & $\mathrm{N}$ & 255 & 255 \\
\hline
\end{tabular}

The data presented in above Table 3, shows the correlation between the two variables of religious motives and personal wish of veiling. The results show a strong correlation between the two factors. It reports a strong correlation coefficient $(r)+0.521(P<0.001)$. It shows that there is a strong likelihood that if female Muslim Malaysian university students report to adopt veiling due to religious motivation, they also report to adopt vailing due to their personal wish and choice. According to the results presented here the null hypothesis is rejected and the alternative hypothesis $\left(\mathrm{H}_{1}\right)$, stating that the mean score acquired on the scale of religious motive of veiling has statistically significant positive correlation with the score on the scale of personal wish to veil among female Muslim Malaysian university students, is accepted. 


\section{Relationship between religious motives and family pressure}

The data was also analyzed and presented to identify any possible relationship between young female Malaysian Muslim university students' veiling due to religious motives and their adoption of this veiling due to the pressure imposed by family members.

\section{Table 4: Descriptive Statistics}

\begin{tabular}{lrrr}
\hline & Mean & Std. Deviation & N \\
\hline Religious motives & 27.8902 & 2.82210 & 255 \\
\hline Family pressure & 7.4235 & 4.04515 & 255 \\
\hline
\end{tabular}

The data analysis presented in above Table 4 shows that young female Malaysian university students $(\mathrm{N}=255)$ who are practicing veiling presently are scoring a mean of $27.8902(d f=2.82210)$ on the scale of religious motives as reason of veiling. At the same time the respondents have scored a mean of $7.4235(d f=4.04515)$ on the scale of adopting veiling due to the pressure imposed by family of these young girls.

Table 5: Correlations between religious motives and the family pressure

\begin{tabular}{llrr}
\hline & \multicolumn{1}{c}{$\begin{array}{c}\text { Religious } \\
\text { motives }\end{array}$} & \multicolumn{2}{c}{$\begin{array}{c}\text { Family } \\
\text { pressure }\end{array}$} \\
\hline Religious & Pearson & 1 & -.037 \\
motives & Correlation &. & .557 \\
& Sig. (2-tailed) & 255 & 255 \\
\hline Family & $\mathrm{N}$ & & 1 \\
pressure & Pearson & -.037 &. \\
& Correlation & .557 &. \\
& Sig. (2-tailed) & 255 & 255 \\
\hline
\end{tabular}


The data analysis presented in Table 5 above show the existence of any possible relationship between young female Malaysian university student's veiling due to religious motives and their adoption of the same veiling due to the pressure exerted by family members. The data show a correlation coefficient $(r)-.037(p>0.05)$. Although, the correlation coefficient appears to be negative (i.e. -.037) but the correlation is not significant as the value of $p$ presented above (i.e. 0.557) shows a non-significant relationship between the two variables. It means there is no relationship between Malaysian Muslim female university students' reports of practicing veiling due to religious motive and simultaneously due to the pressure exerted by family to veil. In the light of above results, the alternative hypothesis $\left(\mathrm{H}_{2}\right)$, stating that the mean score acquired on the scale of religious motive of veiling has statistically significant positive correlation with the mean score on the scale of family pressure to veil among female Muslim Malaysian university students, is rejected. The null hypothesis that there is no relationship between the two factors is accepted.

\section{CONCLUSION}

This research paper was an effort to explore potential relationship between use of veil among female Malaysian Muslim university students due to religious motives and the choice of the veiling made by themselves or their family. A survey was done with Malaysian university students to collect data with the help a closed ended questionnaire. The data used in this research is based on three scales namely practice of veiling due to religious motives, veiling due to personal wish, and veiling due to family pressure. The data was statistically analyzed and the results were presented above. According to the results of statistical analysis, it was inferred that there is a statistically significant strong positive relationship between these students' veiling practice due to religious motives and the veiling out of their personal wish. At the same time, the data analysis 
did not show any statistically significant relationship between these students' veiling practice due to religious motives and their use of veiling because of family pressure.

The research on veiling practices, its purpose and social and political dynamics around it have the potential to uncover various aspects of power dynamics in daily life. It is recommended that future research may attempt to operationally define the dynamics behind variables to provided empirical data on the various aspects of this phenomenon. It will help to make this broadly theoretically addressed phenomenon tangible.

\section{REFERENCES}

Abraham, J. (2018). Hindu and Muslim veiling in north India: Beyond the public/private dichotomy. In A. M. Almila \& D. Inglis (Eds.) The Routledge international handbook to veils and veiling practices (pp. 246-254). New York: Routledge.

Almila, A. M., \& Inglis, D. (Eds.). (2018). The Routledge international handbook to veils and veiling practices. New York: Routledge.

Arshad, M., Basar, S., Zafar, A. R., \& Ahmad, N. (2012). Culture of veil among University students in Pakistan. International Journal of Learning and Development, 2(3), 57-67.

Arshad, M., Irfan, M. K., Zaman, Q., Akhtar, M., \& Shahzad, M. A. (2013). Association of veiling with religious obligation among university students. International Journal of Human Resource Studies, 3(1), 63-73.

Beck, L. G. (1977). Behind the veil by Eve Arnold. American Anthropologist, 79(1), 195-196.

Candraningrum, D. (2013). Negotiating women's veiling: Politics and sexuality in contemporary Indonesia. IRASEC Occasional Paper No.22. Bangkok. 
Chowdhury, N. A., Elmetwally, A. A., \& Bakar, H. S. A. (2017). Misconception of Islamic apparel, niqab: A phenomenological approach. Jurnal Komunikasi: Malaysian Journal of communication, 33(4), 204-217.

Doblado, M. (n. d.). The consequences of unveiling Muslim women. university of Francisco. Retrieved from https://www.usfca.edu/uploadedFiles/Destinations/College_of_ Arts_and_Sciences/Undergraduate_Programs/Theology/Student s/MDoblado.FINAL.pdf

Dwyer, C. (2008). The geographies of veiling: Muslim women in Britain. Geography, 93(3), 140-147.

Elor, T. (2017). 2007/8: The winter of the veiled women in Israel. In A. M, Almila \& D. Inglis (Eds.). The Routledge International Handbook to Veils and Veiling Practices (pp. 63-72). New York: Routledge.

Farhatullah, A., Nizar, S., Ahmad, I., Ali, S. R., \& Shah, S. (2014). Hijab: A sociological analysis of the use and advantages of hijab among female university students in Pakhtun society. Pakistan Journal of Women's Studies: Alam-e-Niswan, 21(1), 105-124.

Frisk, S. (2009). Submitting to God: Women and Islam in urban Malaysia (Paper No. 6). Denmark: Nordic Institute for Asian Studies Press.

Gökarıksel, B., \& Secor, A. (2012). "Even I was tempted": The moral ambivalence and ethical practice of veiling-fashion in Turkey. Annals of the Association of American Geographers, 102(4), 847-862.

Göle, N. (1953). The forbidden modern: Civilization and veiling. University of Michigan Press.

Grine, F., \& Saeed, M. (2017). Is Hijab a fashion statement? A study of Malaysian Muslim women. Journal of Islamic Marketing, 8(3), 430-443. 
Halim, A. S. B. A. (2018). Veiling: Not just about "women and religion" among Malay women in Malaysia. In The Proceedings \& Abstracts of ICONASH 2018, conducted at Antalya.

Hassim, N. (2017). Glocalizing the hijab: A Malaysian perspective. In SHS Web of Conferences, 33, DOI: 10.1051/ shsconf/20173300016.

Hassim, N. (2014). A comparative analysis on hijab wearing in Malaysian Muslimah magazines. The Journal of the South East Asia Research Center for Communications and Humanities, 6(1), 79-96.

Hassim, N. (2014a). Hijab and the Malay-Muslim women in media. Procedia-Social and Behavioral Sciences, 155, 428-433.

Hassim, N., Ishak, M. S. A., \& Nayan, S. M. (2016). The socialization of hijab culture among Malaysian media consumers. Journal of the Southeast Asia Research Centre for Communications and Humanities, 8(2), 62-74.

Hawley, J. M. (2018). The Amish prayer cap as a symbol that bounds the community. In A. M. Almila \& D. Inglis (Eds.). The Routledge international handbook to veils and veiling practices (pp.292-300). New York: Routledge.

Hirschmann, N. J. (1997). Eastern veiling, western freedom? The Review of Politics, 59(3), 461-488.

Hochel, S. (2013). To veil or not to veil: Voices of Malaysian Muslim women. Intercultural Communication Studies, XXII (2), 40-57.

Hoodfar, H. (1991). The Veil in their minds and on our heads: The persistence of Colonial images of Muslim women. Québec: Department of Sociology and Anthropology, Concordia University Montréal.

Human Rights Commission (2005). Muslim women, dress codes and human rights: An introduction to some of the issues. Human Rights Commission. 
Izharuddin, A. (2018). 'Free hair': Narratives of unveiling and the reconstruction of self. Signs: Journal of Women in Culture and Society, 44(1), 155-176.

Lateh, A., \& Mudor, H. (2014). Testing the Muslim students' attitude towards wearing hijab at Prince of Songkla University Pattani Campus, Thailand. International Journal of Asian Social Science, 4(10), 1035-1044.

Latiff, Z. A., \& Alam, F. N. (2013). The roles of media in influencing women wearing hijab: An analysis. Journal of Image and Graphics, 1(1), 50-54.

Leibold, J., \& Grose, T. (2016). Islamic veiling in Xinjiang: The political and societal struggle to define Uyghur female adornment. The China Journal, 76(1), 78-102.

Lie, M. (2000). Two generations: Life stories and social change in Malaysia. Journal of Gender Studies, 9(1), 27-43.

Miller, R. L., Acton, C., Fullerton, D. A., \& Maltby, J. (2002). SPSS for Social Scientists. Hampshire: Palgrave Macmillan.

Mouser, A. E. (2007). Defining 'Modern' Malay womanhood and the coexistent messages of the veil. Religion, 37(2), 164-174.

Naidu, M. (2009). Seeing (through) the gaze: Marking religious and cultural differences onto Muslim female bodies. Journal for the Study of Religion, 22(2), 23-42.

Pasha-Zaidi, N. (2015). The hijab effect: An exploratory study of the influence of hijab and religiosity on perceived attractiveness of Muslim women in the United States and the United Arab Emirates. Ethnicities, 15(5), 742-758.

Reeves, T. C., McKinney, A. P., \& Azam, L. (2012). Muslim women's workplace experiences: Implications for strategic diversity initiatives. Equality, Diversity and Inclusion: An International Journal, 32(1), 49-67, Doi:10.1108/02610151311305614. 
Stivens, M. (2006). 'Family values' and Islamic revival: Gender, rights and state moral projects in Malaysia. Women's Studies International Forum, 29, 354-367.

Sultana, A. M., Jawan, J. A., \& Hashim, I. (2009). Influence of purdah (veil) on education and employment of women in rural communities. European Journal of Social Sciences, 11(2), 267280.

Sunesti, Y. (2016). Veiling: Between social imaginary and the politic of multiculturalism in Indonesia and Malaysia. Musãwa Jurnal Studi Gender dan Islam, 15(2), 145-156.

Thompson, D. (Ed.). (1993). The Oxford dictionary of current English (2nd ed.). Oxford University Press.

Thompson, D. (Ed.). (1997). The concise Oxford dictionary of current English (3 ${ }^{\text {rd }}$ ed.). London: BCA.

Utomo, A., Reimondos, A., McDonald, P., Utomo, I., \& Hull, T. (2018). Who wears the Hijab? Predictors of veiling in greater Jakarta. Review of Religious Research, 60(4), 477-501.

van Santen, J. C. M. (2010). My 'veil' does not go with my jeans': Veiling, fundamentalism, education and women's agency in northern Cameroon, Africa: Journal of the International African Institute, 80(2), 275-300.

Warren, C. S. (2008). Lifting the veil: Women and Islamic law. Faculty Publications (Paper 99). Retrieved from http://scholarship.law.wm.edu/facpubs/99

Yusuf, H. E. (2014). Purdah: A religious practice or an instrument of exclusion, seclusion and isolation of women in a typical Islamic setting of northern Nigeria, American International Journal of Contemporary Research, 4(1), 238-245.

Zahedi, A. (2008). Concealing and revealing female hair: Veiling dynamics in contemporary Iran. In J., Heath (Ed.). The veil: Women writers on its history, lore, and politics (pp. 250-265). California: University of California Press. 